\title{
Cystoid macular edema secondary to immune recovery uveitis in a man with cytomegalovirus retinitis and AIDS
}

This article was published in the following Dove Press journal:

Clinical Ophthalmology

18 September 2010

Number of times this article has been viewed

\section{Kathir Yoganathan}

HIV/Genito-Urinary Medicine, Abertawe Bro Morgannwg University Health Board, Singleton hospital, Swansea, UK
Correspondence: Kathir Yoganathan HIV/GU Medicine, Abertawe Bro Morgannwg University Health Board, Cardiff University Medical School, Singleton hospital, Swansea SA 2 8QA, UK

Tel +44I792 285017

Email kathir.yoganathan@wales.nhs.uk

\begin{abstract}
Cytomegalovirus (CMV) is the most common intraocular opportunistic infection in profoundly immunocompromised patients with AIDS. It is characterized by an acute, progressive, necrotizing retinitis in patients with a CD4 count of $<50$ cells $/ \mu \mathrm{L}$. Although the incidence of CMV retinitis has declined because of the introduction of antiretroviral therapy (ART), a new syndrome of intraocular inflammation has emerged in patients with rising CD4 lymphocyte counts following ART. This is called immune recovery uveitis (IRU). It is thought to occur as a result of restored immunity to various infectious agents, commonly mycobacterial, Cryptococcus, and herpes virus infections. We report a man who was treated for CMV retinitis and later developed IRU in the form of cystoid macular edema (CMO) even though his CMV retinitis remained inactive. His CMO resolved and visual acuity improved 2 years after the onset of CMO without any treatment interventions.
\end{abstract}

Keywords: HIV, cystoid macular edema, AIDS, CMV retinitis

\section{Summary}

Cytomegalovirus (CMV) is the most common intraocular opportunistic infection in profoundly immunocompromised patients with AIDS. It is characterized by an acute progressive necrotizing retinitis in patients with a CD4 count of $<50$ cells $/ \mu \mathrm{L} .{ }^{1}$ Although the incidence of CMV retinitis has declined because of the introduction of antiretroviral therapy (ART), a new syndrome of intraocular inflammation has emerged in patients with rising CD4 lymphocyte counts. This is called immune recovery uveitis (IRU)., ${ }^{2,3}$ It is thought to occur as a result of restored immunity to various infectious agents, commonly mycobacterial, Cryptococcus, and herpes virus infections. ${ }^{4}$ We report a man who was treated for CMV retinitis and later developed IRU in the form of cystoid macular edema $(\mathrm{CMO})$ even though his $\mathrm{CMV}$ retinitis remained inactive.

\section{Case report}

In April 2008, a 45-year-old man presented with floaters and blurring of vision of his right eye for 6 days. Examination of the fundus revealed a nasal area of pallor extending from the periphery towards the centre. The visual acuity was $6 / 24$. There was a moderate vitritis but no evidence of retinal hemorrhages (Figure 1). Examination result of left eye was normal. A diagnosis of acute retinal necrosis was made. Total blood count revealed lymphocytes of $0.5 \times 10^{9} / \mathrm{L}$ and platelets of $107 \times 10^{9} / \mathrm{L}$. Total plasma protein was $92 \mathrm{~g} / \mathrm{L}$. The human immunodeficiency virus (HIV) test was requested and was found positive. The CD4 count was 42 cells $/ \mathrm{mm}^{3}$ (9\%), and HIV RNA (viral load [VL]) level was 1.4 million copies/mL. Polymerase chain reaction (PCR) of the aqueous humor 


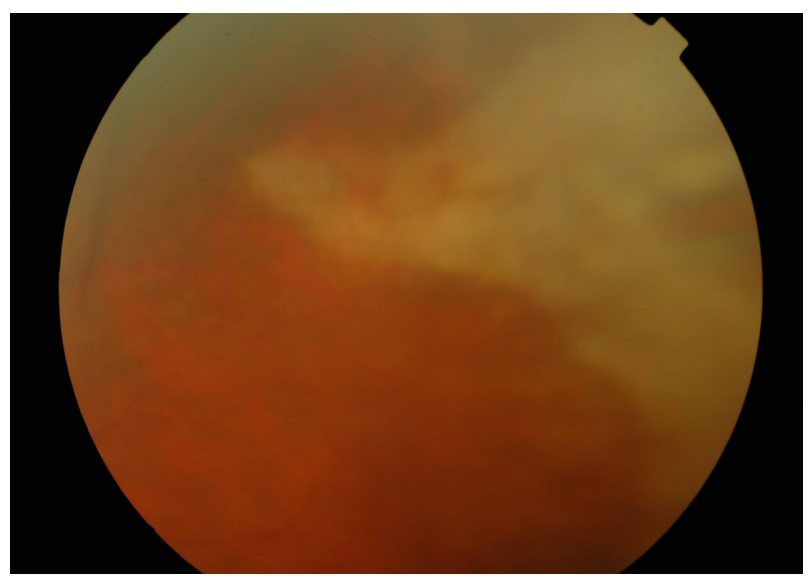

Figure I Nasal pallor extending from periphery towards the center without any evidence of hemorrhages.

was positive for CMV but negative for herpes simplex and varicella-zoster virus. The CMV PCR in blood was $2.5 \times 10^{5}$ copies/mL. He was treated with five courses of intravenous cidofovir. His CMV PCR in the blood became undetectable. ART was commenced in June 2008. After 4 weeks of ART, the CD4 count had risen to 200 cells $/ \mathrm{mm}^{3}$ (18\%), and VL dropped to 6,602. Visual symptoms improved. In October 2008 , he noticed blurring of vision in the right eye with a visual acuity of $6 / 24$. His optical coherence tomography (OCT) scan showed CMO (Figure 2). Fundoscopy did not show any evidence of active CMV retinitis. The patient declined intravitreal triamcinolone. In April 2010, his visual acuity improved to a level of 6/12. The OCT of the right fundus showed a normal foveal dip.

\section{Discussion}

In a study by Karavellas et al, ${ }^{5}$ the prevalence of IRU varied from $38 \%$ to $63 \%$ in patients with CMV retinitis. The median

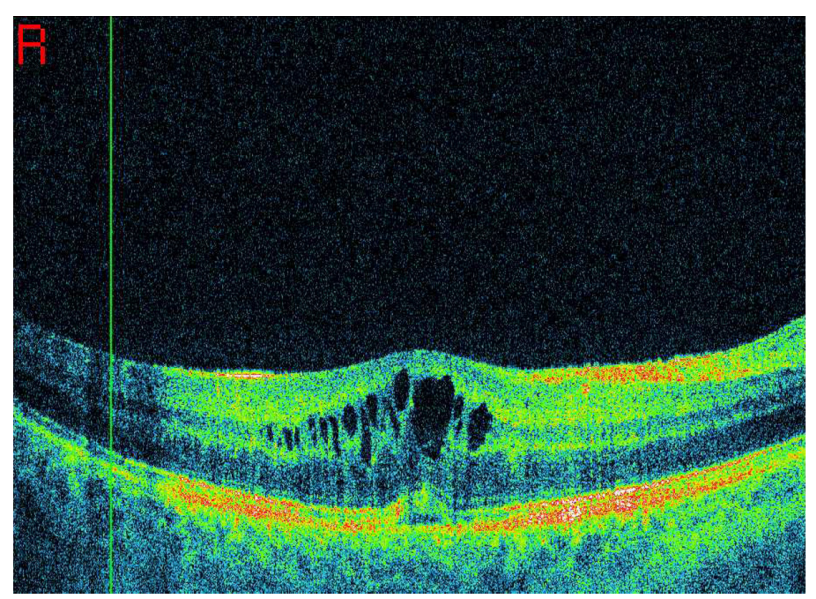

Figure 2 Optical coherence tomography showing cystoid macular edema. time to develop IRU was 45 weeks. Our patient developed IRU 8 weeks after ART. IRU is associated with CMV retinitis and rapid increases in CD4 counts following ART. Our patient developed CMV retinitis and responded well to ART by showing a rise in CD4 counts and a dramatic drop in VL. As in our patient, in a study by Karevellas et $\mathrm{al}^{6}$ all patients with IRU had inactive CMV retinitis at their presentation. CMV-related vitritis has been reported before the introduction of ART but was associated with active CMV retinitis.

The clinical spectrum of IRU includes vitritis, CMO, epiretinal membranes, and papillitis. ${ }^{6}$ Our patient developed CMO. Another risk factor for IRU includes surface area of retinal involvement due to CMV retinitis. Patients with $>30 \%$ of retinal area affected had 4.5 -fold higher risk of developing IRU when compared with eyes with a retinal CMV area of $<18 \%{ }^{7}$

Immunohistological examination of epiretinal membrane associated with IRU showed evidence of chronic inflammation with predominant T-lymphocytes. This data, in conjunction with the finding of a positive correlation between IRU and surface area of inactive CMV retinitis, would suggest that IRU may be due to T-cell mediated reaction to CMV antigen present in inactive CMV retinitis. ${ }^{8}$ The question is whether anti-CMV therapy may provide effective treatment for IRU. Although a study showed a beneficial effect of valganciclovir, other studies failed to prove any beneficial effects. ${ }^{89}$

Four cases with $\mathrm{CMO}$ were treated with various treatments: one with a systemic prednisolone, two with injections of triamcinolone, ${ }^{10,11}$ and one with oral acetazolamide and local ketorolac trimethamine. Visual acuity improved by one line in all patients. In another study, corticosteroid treatment for five severe cases of IRU resulted in improvement in visual acuity without any reactivation of CMV retinitis. However, the use of steroid did not influence the outcome of patients whether they were treated early or those who were treated later. His CMO resolved 2 years following the onset without any steroid or anti-CMV treatment.

In conclusion, ophthalmologists who have a patient with acute retinal necrosis should be alert to the possibility of underlying HIV infection and CMV retinitis. This is particularly important in patients with lymphopenia, thrombocytopenia, and high globulin as in our case. In addition, a deterioration of visual acuity in patients who have been treated for CMV retinitis does not necessarily indicate a relapse. Clinicians should be aware of IRU in patients who respond to ART and consider clinical observation with masterly inactivity because in some patients the condition is mild 
and transient, as in our case. Local steroid injection may be indicated in severe cases of macular edema.

\section{Acknowledgment}

I would like to thank Mr Mohammed Muhtaseb for supplying the retinal photo and optical coherence tomography imaging.

\section{Disclosure}

The author reports no conflict of interest in this work.

\section{References}

1. Kuppermann BD, Petty JG, Richmand DD, et al. Correlation between $\mathrm{CD}^{+}$count and prevalence of cytomegalovirus retinitis and human immunodeficiency virus-related non-infectious retinal vasculopathy in patients with acquired immunodeficiency syndrome. Am J Ophthalmol. 1993; 115:575-582.

2. Jacobson MA, Stanley H, Holtzer C, et al. Natural history and outcome of new AIDS-related retinitis diagnosed in the era of highly active antiretroviral therapy. Clin Infect Dis. 2000;30:231-233.

3. Nguyen QD, Kempen JH, Bolton SG, et al. Immune recovery uveitis in patients with AIDS and cytomegalovirus retinitis after highly active antiretroviral therapy. Am J Ophthalmol. 2000;129:634-639.
4. Bopage R, Yoganathan K. CMV cholangiopathy in HIV infected man following HAART: immune recovery inflammatory syndrome. $H I V$ Med. 2006;7:36.

5. Karavellas MP, Plummer DJ, Macdonald JC, et al. Incidence of immune recovery vitritis in cytomegalovirus retinitis patients following institution of successful highly active antiretroviral therapy. J Infect Dis. 1999;179:697-700.

6. Karavellas MP, Lowder CY, Macdonald JC, Avila CP, Freeman WR. Immune recovery vitritis associated with inactive CMV retinitis: a new syndrome. Arch Ophthalmol. 1998;116:169-175.

7. Karavellas MP, Azen SP, Macdonald JC, et al. Immune recovery vitritis and uveitis in AIDS clinical predictors, sequelae and treatment outcomes. Retina. 2001;21:1-9.

8. Kosobucki BR, Goldberg DE, Bessho K, et al. Valganciclovir therapy for immune recovery uveitis complicated by macular edema. Am J Ophthalmol. 2004;137:636-638.

9. Song MK, Azen SP, Buley A, et al. Effect of anti-cytomegalovirus therapy on the incidence of immune recovery uveitis in AIDS patients with healed cytomegalovirus retinitis. Am J Ophthalmol. 2003;136: 696-602.

10. Morrison VL, Kozak I, LaBree LD, Azen SP, Kayioglu OO, Freeman WR. Intravitreal triamcinolone acetonide for the treatment of immune recovery uveitis macular edema. Ophthalmology. 2007;114: 334-339.

11. Henderson HWA, Mitchell SM. Treatment of immune recovery vitritis with local steroids. Br J Ophthalmol. 1999;83:540-545.
Clinical Ophthalmology

\section{Publish your work in this journal}

Clinical Ophthalmology is an international, peer-reviewed journal covering all subspecialties within ophthalmology. Key topics include: Optometry; Visual science; Pharmacology and drug therapy in eye diseases; Basic Sciences; Primary and Secondary eye care; Patient Safety and Quality of Care Improvements. This journal is indexed on

Submit your manuscript here: http://www.dovepress.com/clinical-ophthalmology-journal

\section{Dovepress}

PubMed Central and CAS, and is the official journal of The Society of Clinical Ophthalmology (SCO). The manuscript management system is completely online and includes a very quick and fair peer-review system, which is all easy to use. Visit http://www.dovepress.com/ testimonials.php to read real quotes from published authors. 